\title{
Use of Soil Water Retention Capacity and Hydraulic Conductivity Estimation in the Preparation of Soil Water Management Maps
}

\author{
${ }^{1}$ B. TÓTH, ${ }^{1}$ A. MAKÓ, ${ }^{2}$ K. RAJKAI, ${ }^{3}$ G. SZ. KELE, ${ }^{1}$ T. HERMANN and ${ }^{4} \mathrm{P}$. MARTH \\ ${ }^{1}$ University of Veszprém, Georgikon Faculty of Agriculture, Keszthely (Hungary), \\ ${ }^{2}$ Research Institute for Soil Science and Agricultural Chemistry of the Hungarian Acad- \\ emy of Sciences, Budapest, ${ }^{3}$ Plant Protection and Soil Conservation Service of Fejér \\ County, Velence (Hungary) and ${ }^{4}$ Central Plant Protection and Soil \\ Conservation Service, Budapest
}

The demand for soil hydraulic data in Hungary has grown with the availability and increased application of different hydrophysical models. In general the knowledge of soil's hydraulic properties is of major importance in agriculture, as they have significant effects on soil fertility, soil aeration, soil temperature, drainage, irrigation and cultivability (PUCKETT et al., 1985; VÁRALLYAY, 2004, 2005a,b). The most common hydraulic properties are the hydraulic conductivity and soil water retention capacity. The measurement of these soil properties, however, is costly, labour and time consuming. It is necessary therefore to have a balance between direct measurement and estimations having variable uncertainty.

In order to derive numerical values of soil water retention and hydraulic conductivity for regional soil water simulation models soil survey data were applied (e.g. WÖSTEN et al., 1985). The measured soil hydrophysical data were organized into soil physical databases, such as UNSODA (LEIJ et al., 1999), HYPRESS (WÖSTEN et al., 1999), HUNSODA (NEMES, 2002), GRIZZLY (HAVERKAMP et al., 1998) etc. These large databases are used for estimating continuous and/or class pedotransfer functions (WÖSTEN et al., 1995). Class pedotransfer functions are suitable for estimating the water retention characteristics and conductivity function for soil groups. The pedotransfer functions can be checked for the database by the bootstrap method (SHAAP et al., 1999), their wider application may, however, involve significant uncertainty. For this reason local and methodically consistent datasets are also used for deriving pedotransfer functions (e.g. STEKAUEROVA et al., 2003; RAJKAI et al., 2004; JENSEN et al., 2005).

Indirect methods for estimating hydraulic properties from more easily measured soil properties (i.e. from soil texture, bulk density, organic matter content) have been applied widely (e.g. AHUJA et al., 1985; FODOR \& RAJKAI, 2004; RAJKAI et al., 2004). In addition to that other information, as field topographic attributes (PACHEPSKY et al., 2001; RAWLS \& PACHEPSKY, 2002), and the combination of

Correspondence to: BRIGITTA TÓTH, University of Veszprém, Georgikon Faculty of Agriculture, H-8360 Keszthely, Deák F. út 16. Hungary. E-mail: gema@freemail.hu 
physical data and terrain attributes are also applied (ROMANO \& PALLADINO, 2002). ANDERSON and BOUMA (1973) and BOUMA et al. (1979) predicted the saturated hydraulic conductivity $\left(\mathrm{K}_{\mathrm{sat}}\right)$ values from morphometric soil data, KING and FRANZMEIER (1981) related $\mathrm{K}_{\text {sat }}$ values to soil texture, parent material, and genetic horizon. MCKEAGUE et al. (1982) related measured $\mathrm{K}_{\text {sat }}$ values to soil structure, porosity, biopores, soil texture, consistency and density, and then they created $\mathrm{K}_{\text {sat }}$ classes for soil horizons. Since the conventional morphological data used for soil classification and mapping are difficult to analyze statistically, functional morphological descriptors are used to describe the morphological characteristics of the soils (e.g. BOUMA, 1989; MCKENZIE \& JACQUIER, 1997; CRESSWELl et al., 1999).

The taxonomical classes (soil type or subtype) also integrate numerous unknown or less known physical, chemical, mineralogical and morphological soil properties. Knowing this we used the Hungarian Soil Information and Monitoring System's (HSIMS) database for estimating the water retention characteristics of brown forest soils from the exploratory grouped mean data, soil subtype, texture and humus content codes of the soil maps (MAKÓ et al., 2005).

Soil maps visualize the information collected by the standard soil surveys. Soil maps indicate not only the soil type, but also other soil attributes in certain categories. One of the most widespread applications of soil maps is land use planning. For this purpose soil maps in the scale of 1:10.000 are used, which are available for about $60 \%$ of the agricultural area of Hungary (То́тH et al., 2006).

Soil physical properties and soil water regime are in the focus of soil survey in Hungary due to waterlogging and drought. The first Hungarian large-scale water management cartogram was constructed by SARKADI et al. (1964). The Hungarian laws in force prescribe the preparation of a water management cartogram by the expert's reports written on the subject of drainage, irrigation, liquid manure, sewage or sewage-sludge disposal (MÉM, 1984).

VÁRALLYAY et al. (1980) elaborated a category system for the planning of water management. The map of these categories was prepared in the scale of 1:100.000. The category system was used for preparing the 1:10.000 water management cartograms as well.

Later VÁRALLYAY et al. (1989) elaborated another category system for largescale $(1: 10.000)$ mapping on the basis of soil hydrophysical properties and soil moisture regime's characteristics. The map indicates the soil texture of the topsoil (10 categories); bulk density $\left(\mathrm{g} / \mathrm{m}^{3}\right)$ (5 categories); maximum water capacity (vol. $\%)$ (7 categories); field capacity (vol. \%) (10 categories); wilting percentage (vol. $\%)$ (10 categories); available moisture range (vol. \%) (8 categories); saturated hydraulic conductivity (cm/day) (10 categories); capillary water transport rate (mm/year) (6 categories); soil layering (10 categories); average depth of the groundwater $(\mathrm{m})$ ( 7 categories). From the above-mentioned parameters ten-digit codes were established. The soil water management mapping method was named "Physical and Water management properties, the Water regime of soils" (PWW). The preparation of PWW maps requires a great amount of hydrophysical data from the mapped field. Perhaps this is the main reason why this type of mapping method is not spread around Hungary. 
The aim of the present work was to analyze the accuracy of the estimated hydrophysical soil properties from the data available on soil maps and cartograms of a study area. The usefulness of the estimated hydrophysical data for the large-scale characterization of soil water management was also evaluated.

\section{Materials and Methods}

In the presented study the Hungarian Soil Information and Monitoring System's (HSIMS) database and measured data of a study field were used. Soil map category codes were generated for the HSIMS database. On the basis of category codes soils of the database were grouped and the hydrophysical properties of the category groups were averaged. The group mean values were used for elaborating the estimation procedures.

The HSIMS database consists of field and laboratory data of soils in Hungary. At present soil physical data of about 1023 profiles are ready for processing. There are information among others about the essential soil properties, particle size distribution and water retention data. Measured values of water retention curves are available for 3115 soil horizons. The soil chemical, physical and hydrophysical parameters of the database were determined according to the Hungarian standards (VÁRALLYAY, 1995).

Testing of the estimations was carried out on a 600-hectare study area located in the confines of the villages Csősz and Tác in Fejér county (Hungary). The soil survey of the study area was conducted by the Plant Protection and Soil Conservation Service of Fejér County. In the study field 59 soil profiles and 16 augured ones were dug. The hydraulic conductivity of the soil was measured by the "augur hole" and the "hole filling" methods in the augered profiles. Undisturbed and disturbed soil samples were collected from the soil profiles. In addition to the main soil physical (particle size fraction; plasticity; water retention) and chemical properties ( $\mathrm{pH}$ in water; sum of water soluble salts; alkalinity; $\mathrm{CaCO}_{3}$ content; organic matter; cation exchange capacity; electrical conductivity of soil water) were determined. The soil types of the study area are as follows: Silti-Calcaric Phaeozems, CalcariGleyic Phaeozems, Sodi-Gleyic Phaeozems, Calci-Mollic Gleysols and Molli-Sodic Gleysols (WRB, 1998).

The soil water retention capacity was predicted from the group mean water retention data of the HSIMS (TÓTH et al., 2005). This estimation requires the "soil water regime type" (SWRT) and soil texture category data. The SWRT generation from the soil subtype was done by MAKÓ et al. (2005). Soil subtypes having similar soil water retention capacity were collected into larger groups (SWRT) by hierarchical cluster analysis (SPSS, HCA). Finally 33 soil groups were created. The estimated water retention capacity group mean data can be compared to those measured for the soil profiles of the study area. For the comparison we used the $\mathrm{pF} 0, \mathrm{pF} 2.5$ and $\mathrm{pF} 4.2$ values, the available water content of all horizons of each profile in the study area. Following RAJKAI et al. (2004), the goodness of the predicted water retention data was evaluated. Water retention prediction is "good" if the mean esti- 
mation error for all three retention data was less than $2.5 \%$. The estimation efficiency (EE) was defined as the percentage of "good" predictions.

For estimating the soil hydraulic conductivity a new method was worked out on the HSIMS database. As the database does not contain measured hydraulic conductivity data $\left(\mathrm{K}_{\mathrm{sat}}\right)$, it was calculated by the Campbell method $\left(\mathrm{K}_{\mathrm{sat}, \mathrm{c}}\right)$ (CAMPBELL, 1974). We assumed the estimated $K_{\text {sat }}$ as the minimum hydraulic conductivity of the soil since it gives the water conductivity of the soil matrix without macro-pores (RAJKAI, 2004). For testing the $\mathrm{K}_{\text {sat }}$ estimation the HSIMS dataset was divided into two parts quasi-randomly. $67 \%$ of the database was used as "evaluation database", the remainder as "test database". In the "evaluation database" seven soil texture groups were generated because particle size data was found to be the most deterministic soil parameter of $\mathrm{K}_{\text {sat }}$ in our former studies (ТóTH et al., 2006). The mean values of sand $\%(0.02-0.2 \mathrm{~mm})$, silt $\%(0.002-0.02 \mathrm{~mm})$, clay $\%(<0.002 \mathrm{~mm})$ and bulk density were calculated for all groups. These mean values were applied in the estimation of the mean saturated hydraulic conductivity $(\mathrm{m} / \mathrm{s})\left(\mathrm{MEAN} \mathrm{K}_{\mathrm{sat}, \mathrm{c}}\right)$ for each texture group (CAMPBELL, 1974). The texture grouping was done for the "test database", as well. In the "evaluation database" calculated MEAN $\mathrm{K}_{\text {sat,c }}$ values were adjoined to the "test database". Additionally, the $\mathrm{K}_{\text {sat, }}$ values of each sample in the "test database" were estimated according to Campbell, and compared to the group means (MEAN $K_{\text {sat,c }}$ ) to control the group estimation. The $K_{\text {sat,c }}$ and the MEAN $\mathrm{K}_{\text {sat, } \mathrm{c}}$ were considered similar when their difference was less than 1 logarithm base 10 (FODOR \& RAJKAI, 2004; SHAAP et al, 1999). The efficiency of estimation was calculated for all samples of the "test database".

The MEAN K $\mathrm{sat}_{\mathrm{c}}$ value (originating from the HSIMS "evaluation database") was adjoined to the soil profiles according to their texture class. The difference between the $\mathrm{K}_{\mathrm{sat}, \mathrm{c}}$ values and the MEAN $\mathrm{K}_{\mathrm{sat}, \mathrm{c}}$ values was evaluated. Due to the fact that measured hydraulic conductivity values were available for the 16 augered profiles in the study area, the MEAN $\mathrm{K}_{\mathrm{sat,c}}$ values were compared with them, as well.

The soil bulk density was also estimated, because frequently there is no available information about this soil parameter. The bulk density estimation method was worked out on the HSIMS database. The mean bulk density values (MEAN BD) were calculated for the soil groups generated by the map codes of the SWRT and soil texture categories. For the soil profiles of the study area, the bulk density was adjoined as the MEAN BD of the adequate soil group. The difference between the measured and the estimated bulk densities was evaluated.

The capillary water transport rate can also be estimated from the soil texture, the depth of the groundwater table and the soil layering (GIESEL et al., 1972; ANLAUF et al., 1990). This estimation was done for the study area, as well. No control of the prediction could be made because of the lack of measurements.

If soil layering is missing from field or laboratory reports, it can be estimated from the soil subtype. 


\section{Results and Discussion}

A conventional soil water regime cartogram was prepared for the study area using the measured hydrophysical data according to the 1:100.000 mapping method (VÁRAlLYAY, 1980). A PWW map was prepared with the 10-digit PWW codes (VÁRALLYAY et al., 1989) for the soil profiles of the study area using the estimated (bulk density; $\mathrm{pF}$ values; hydraulic conductivity; capillary water transport rate) and the measured data (soil texture; soil layering; average depth of the groundwater table). The two maps were compared with each other.

Interpretation of the PWW codes (each of them represented by a numerical value):

$1^{\text {st }}$ digit: The soil texture of the upper horizons of the soil profiles was taken directly from the soil type map and used in the PWW map.

$2^{\text {nd }}$ digit: The bulk density of soil layers was estimated, with low efficiency. The measured values varied between 1.30 and $1.70 \mathrm{~g} / \mathrm{cm}^{3}$, while the MEAN BD of the soil of the HSIMS ranged from 1.30 to $1.44 \mathrm{~g} / \mathrm{cm}^{3}$. The difference can come from the lowered variance of the averages in the MEAN BD. The used BD estimation did not consider shrinkage and swelling of the clayey soils and their effect on soil bulk density.

$3^{\text {rd }}, 4^{\text {th }}, 5^{\text {th }}$ and $6^{\text {th }}$ digits: The estimated soil water retention at $\mathrm{pF} 0, \mathrm{pF} 2.5$ and $\mathrm{pF} 4.2$ values and the available moisture range were compared to the measured data of the study area. The estimation efficiency of the prediction was 54\%. Allowing less than $3 \%$ estimation error, the proportion of good prediction increased to $70 \%$. Leaving out the $\mathrm{pF} 0$ values the estimation efficiency improved to $78 \%$.

$7^{\text {th }}$ digit: The efficiency of the hydraulic conductivity estimations was $78-79 \%$ in case of the HSIMS database. The difference between the $\mathrm{K}_{\mathrm{sat}, \mathrm{c}}$ and the MEAN $\mathrm{K}_{\mathrm{sat}, \mathrm{c}}$ values of the soil profiles in the case study area were within 1 logarithm base 10 for all samples. Comparing the measured $\mathrm{K}_{\text {sat }}$ values with the MEAN K $\mathrm{K}_{\text {sat,c }}$ values, the estimation efficiency was $46 \%$. The reason of the difference between the estimated and the measured water conductivity may be that field measurements reflect macropores, while the Campbell estimation doesn't.

$8^{\text {th }}$ digit: The estimated water transport rates within the soil profiles were higher than $50 \mathrm{~mm} /$ year in all cases.

$9^{\text {th }}$ and $10^{\text {th }}$ digits: For the study area soil layering and the average depth of the groundwater table were available. No estimation was applied.

Comparing the PWW and the conventional soil water regime cartograms (Fig. 1) it can be assumed that the PWW map quantitatively characterizes the hydraulic soil properties and the soil water regime, while the conventional cartogram serves rather qualitative information. In this respect the PWW cartogram can be used advantageously for field or regional scale water flow modelling purposes. 


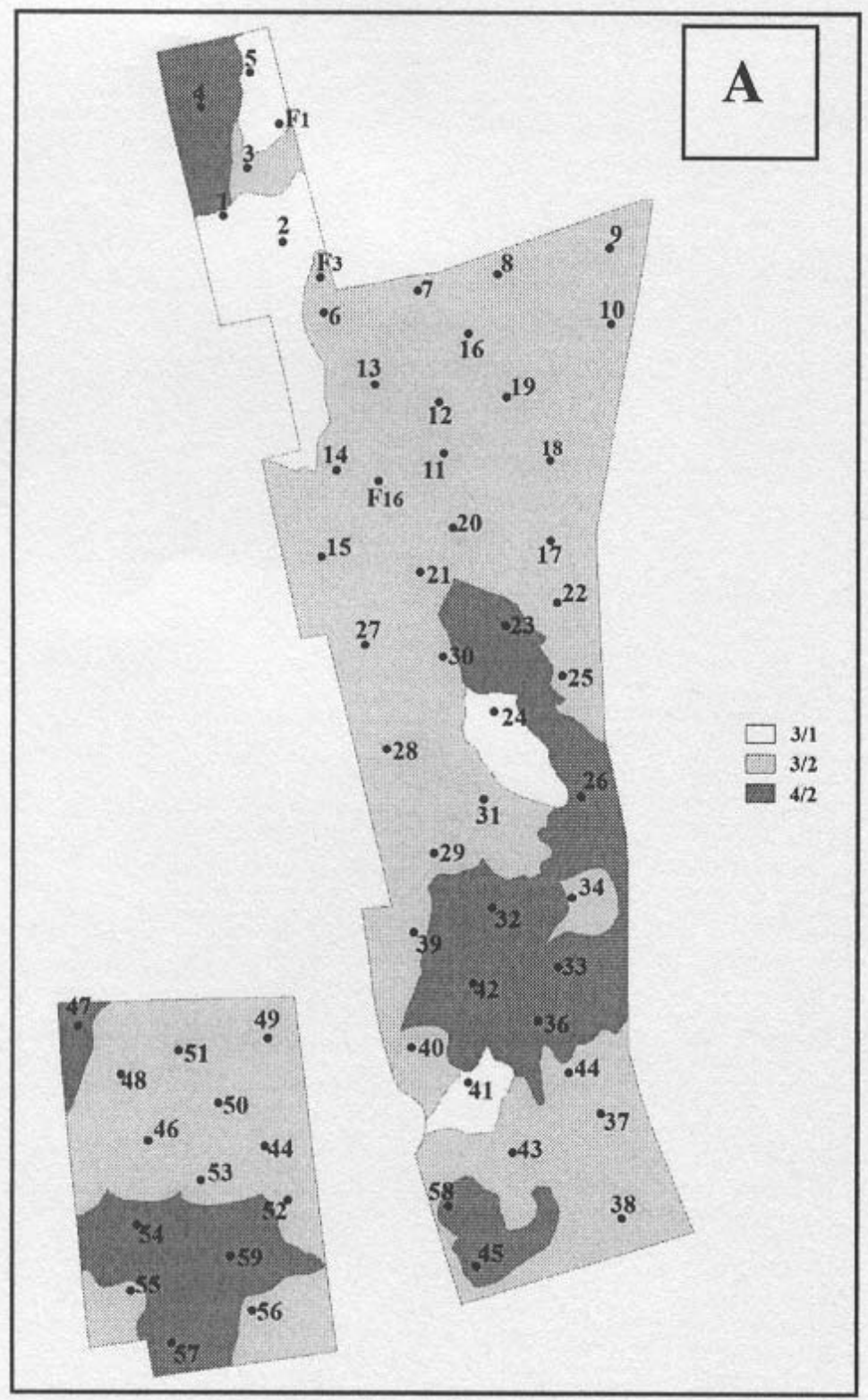

Fig. 1A

Soil water regime cartograms of the case study area A. Conventional water regime cartogram

Legend shows the water regime categories (VÁRALLYAY, 1980) 


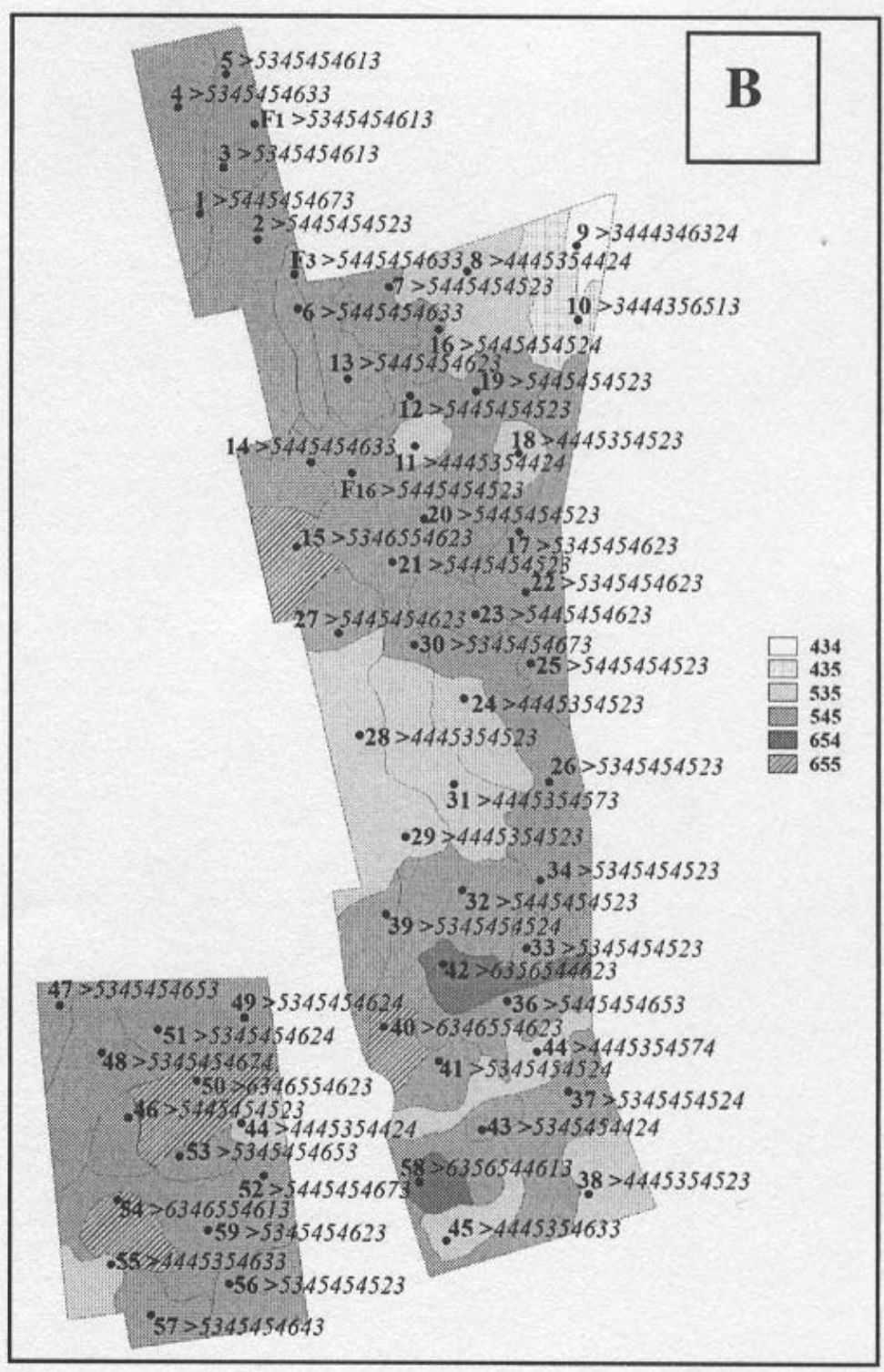

Fig. $1 B$

Soil water regime cartograms of the case study area B. The PWW cartogram.

Legend shows the $3^{\text {rd }}, 4^{\text {th }}$ and $5^{\text {th }}$ codes of the PWW matrix (Numbers in italics are the 10-digit code of the PWW matrix) 


\section{Summary}

According to the Hungarian Soil Information and Monitoring System's (HSIMS) database a group estimation method was developed to predict the mean soil hydrophysical properties. The estimation efficiency of the worked out prediction procedures was controlled on a test database, and on a dataset of a study area. It can be established that the water retention and the hydraulic conductivity of soils are sufficiently predictable from the category data of soil maps.

The 10-digit map codes of the PWW mapping method were created by different estimation methods, and as a result the PWW map was drawn. However, it is not always possible to estimate the necessary soil hydrophysical properties from the available map information for preparing the PWW map. Sometimes the knowledge gained from the field reports is needed as well. Further studies are planned for integrating these morphological information into our estimations.

The present work was supported by the National Scientific Research Fund (OTKA) under grant No. T048302.

Key words: water retention, hydraulic conductivity, group estimation, soil mapping, soil water regime

\section{References}

Ahuja, L. R., NANEY, J. W. \& Williams, R. D., 1985. Estimating soil water characteristics from simpler properties or limited data. Soil Sci. Soc. Am. J. 49. 1100-1105.

ANDERSON, J. L. \& BOUMA, J., 1973. Relationships between saturated hydraulic conductivity and morphometric data of an argillic horizon. Soil Sci. Soc. Amer. Proc. 37. 408-413.

Anlauf, R. et al., 1990. Models for Processes in the Soil. Catena. Cremlingen-Destedt.

BoumA, J., 1989. Using soil survey data for quantitative land evaluation. Adv. Soil. Sci. 9. 177-213. Springer Verlag. New York. NY.

Bouma, J., Jongerius, A. \& SCHOONDERBEEK, D., 1979. Calculation of saturated hydraulic conductivity of some pedal clay soils using micromorphometric data. Soil Sci. Soc. Am. J. 43. 261-264.

CAMPBEll, G. S., 1974. A simple method for determining unsaturated conductivity from moisture retention data. Soil. Sci. 117. 311-314.

Cresswell, H., MCKenZie, N. \& PAydar, Z., 1999. Strategy for determining hydraulic properties of Australian soils using direct measurements and pedotransfer functions. In: Proc. Int. Workshop on Characterization and Measurement of the Hydraulic Properties of Unsaturated Porous Media. (Eds.: VAN GENUCHTEN, M. TH., LEIJ, F. J. \& WU, L.) 1143-1160. University of California. Riverside, CA.

FODOR, N. \& RAJKAI, K., 2004. Estimation of physical soil properties and their use in models. (In Hungarian) Agrokémia és Talajtan. 53. 225-238. 
Giesel, W., Renger, M. \& Strebel, O., 1972. Berechnung des kapillaren Aufstiegs aus dem Grundwasser in den Wurzelraum unter stationaren Bedingungen. Zt. Pflanzenern. Bodenk. 132. 17-30.

HAVERKAMP, R. et al., 1998. GRIZZLY, Grenoble Catalogue of Soils: Retention and Hydraulic Conductivity Functions. Laboratoire d'Etude des Transfers en Hydrologie et Environment (LTHE). Grenoble. France.

Jensen, N. H., Balstrom, T. \& Breuning-Madsen, H., 2005. The relations between soil water retention characteristics, particle-size distributions, bulk densities and calcium carbonate contents for Danish soils. Nordic Hydrology. 36. 235-244.

KING, J. J. \& FRANZMEIER, D. P., 1981. Estimation of saturated hydraulic conductivity from soil morphological and genetic information. Soil Sci. Soc. Am. J. 45. 1153 1156.

LEIJ, F. J. et al., 1999. The UNSODA unsaturated soil hydraulic database. In: Proc. Int. Workshop on Characterization and Measurement of the Hydraulic Properties of Unsaturated Porous Media. (Eds.: van Genuchten, M. Th., LeiJ, F. J. \& Wu, L.) 1269-1281. University of California. Riverside, CA.

MAKÓ, A. et al., 2005. Estimating soil water retention characteristics from the soil taxonomic classification and mapping information: consideration of humus categories. Cereal Research Communications. 33. 113-116.

McKeague, J. A., Wang, C. \& TopP, G. C., 1982. Estimating saturated hydraulic conductivity from soil morphology. Soil Sci. Soc. Am. J. 46. 1239-1244.

MCKENZIE, N. J. \& JACQUIER, D. W., 1997. Improving the field estimation of saturated hydraulic conductivity in soil survey. Aust. J. Soil Res. 35. 803-825.

NemES, A., 2002. Unsaturated Soil Hydraulic Database of Hungary: HUNSODA. Agrokémia és Talajtan. 51. 17-26.

PACHEPSKY, YA., TIMLIN, D. \& RAWLS, W. J., 2001. Soil water retention as related to topographic variables. Soil Sci. Soc. Am. J. 65. 1787-1795.

Puckett, W. E., DANE, J. H. \& HAJEK, B. F., 1985. Physical and mineralogical data to determine soil hydraulic properties. Soil. Sci. Soc. Am. J. 49. 831-836.

RAJKAI, K., KABOS, S. \& VAN GENUCHTEN, M. TH., 2004. Estimating the water retention curve from soil properties: comparison of linear, nonlinear and concomitant variable methods. Soil and Tillage Research. 79. 145-152.

RAWLS, W. J. \& PACHEPSKY, YA., 2002. Using field topographic descriptors to estimate soil water retention. Soil Sci. 167. 423-435.

Romano, N. \& Palladino, M., 2002. Prediction of soil water retention using soil physical data and terrain attributes. J. Hydrology. 265. 56-75.

SARKADI, J., SzÜCS, L. \& VÁRAllyAY, GY., 1964. Large-scale Genetic Agricultural Soil Maps. (In Hungarian) OMMI Genetikus Talajtérképek Ser. 1. No. 8. Budapest.

ShaAP, M. G., LeiJ, F. J. \& VAn Genuchten, M. Th., 1999. A bootstrap-neural network approach to predict soil hydraulic parameters. In: Proc. Int. Workshop on Characterization and Measurement of the Hydraulic Properties of Unsaturated Porous Media. (Eds.: VAn Genuchten, M. TH., LeIJ, F. J. \& WU, L.) 1237-1250. University of California. Riverside, CA.

Stekauerova, V., Sutor, J. \& FArKas, Cs., 2003. Evaluation of soil pedotransfer functions for soils of the Csallóköz and Szigetköz Regions. Acta Agron. Hung. $\mathbf{5 1 .}$ $355-367$. 
То́тн, B. et al., 2005. The estimation possibilities of the soil water retention capacity on the basis of available soil map information. In: $13^{\text {th }}$ International Poster Day "Transport of Water, Chemicals and Energy in the System Soil-Crop CanopyAtmosphere", Bratislava. (Eds.: Celkova, A. \& MATEJKA, F.) 557-562.

TóTH, B. et al., 2006. Study on the estimation possibilities of soil hydraulic conductivity. Cereal Research Communications. 34. (1) 327-330.

TÓth, G., MAKÓ, A. \& MÁTÉ, F., 2006. Designation of local varieties in the Hungarian soil classification system: remarks from the application viewpoint. Eurasian Soil Science. (In press)

VÁRAllyAY, GY. (Ed.), 1995. Hungarian Soil Information and Monitoring System. I. Methodology. (In Hungarian) FM Növényvédelmi és Agrárkörnyezetgazdálkodási Föosztálya. Budapest.

VÁRAllyay, GY. et al., 1980. Soil water management categories of Hungarian soils and the map of soil hydrophysical properties. (In Hungarian) Agrokémia és Talajtan. 29. 77-112.

VÁRALLYAY, GY., 1989. Mapping of hydrophysical properties and moisture regime of soils. Agrokémia és Talajtan. 38. 800-817.

VÁRALlyAY, GY., 2004. The agro-ecological aspects of soil water management. (In Hungarian) AGRO-21 Füzetek. 37. 50-70.

VÁRALlyAY, GY., 2005a. Water storage capacity of Hungarian soils. (In Hungarian) Agrokémia és Talajtan. 54. 5-24.

VÁRALLYAY, GY., 2005b. Soil water management and the environment. In: Environmental Science and Technology in Hungary. (Ed.: LÁNG, I.) 249-259. (CD ROM)

World Reference Base for Soil Resources, 1998. FAO-ISRIC-ISSS. Rome.

WÖSTEN, J. H. M., BouMA, J. \& STOFFELSEN, G. H., 1985. Use of soil survey data for regional soil water simulation models. Soil Sci. Soc. Am. J. 49. 1238-1244.

Wösten, J. H. M., Finke, P. A. \& Jansen, M. J. W., 1995. Comparison of class and continuous pedotransfer functions to generate soil hydraulic characteristics. Geoderma. 66. 227-237.

WÖSTEN, J. H. M. et al., 1999. Development and use of a database of hydraulic properties of European soils. Geoderma. 90. 169-185. 